\title{
Gaze of the Medusa: The Defeat of Hillary Clinton
}

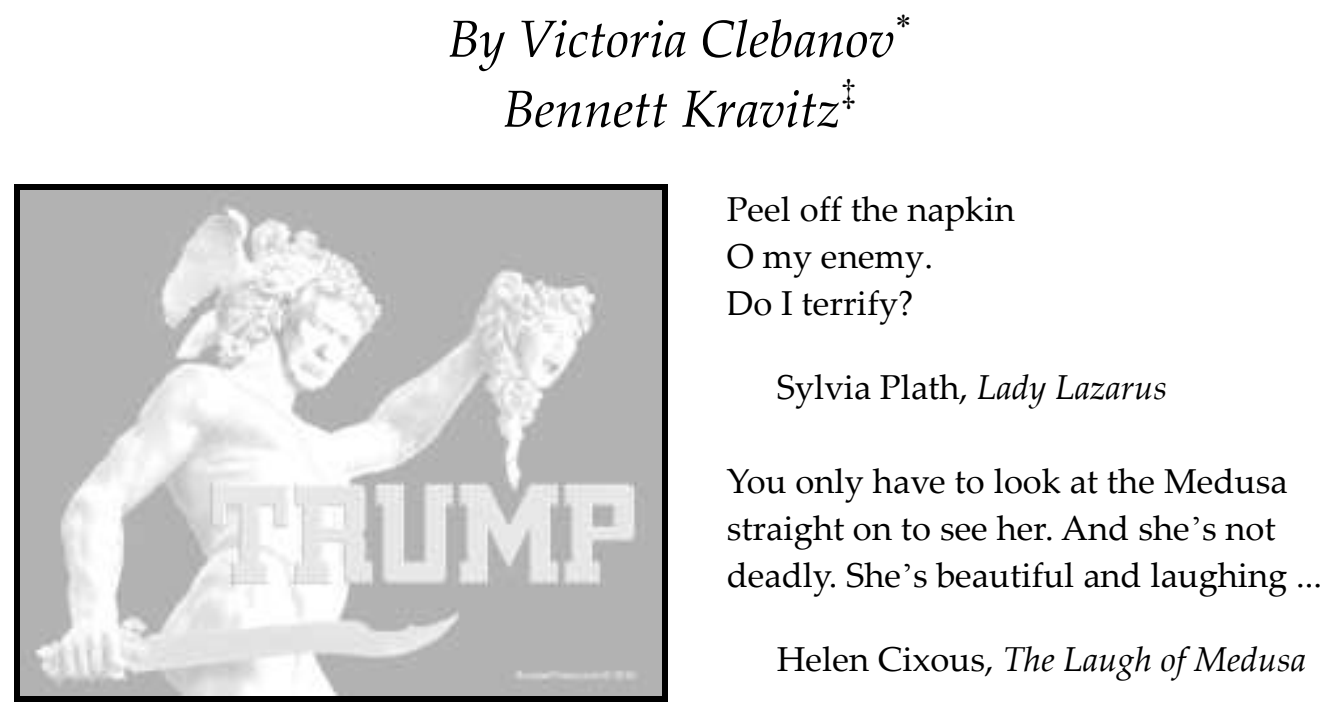

This essay ventures a post-election reflection on the significance of Clinton's defeat by addressing its emblematic representation as Medusa's decapitation by the triumphant Perseus. It is not a coincidence, we argue, that Clinton triggered in public imagination the odious image of Medusa, the epitome of female monstrosity of all [patriarchal] times, while Trump's imagery of his rival articulated the ancient angst of man: the fear of woman as a mirror of man's own monstrosity, the inability to tolerate ambiguity embedded in woman, the envy of incapacity to create life ("uterus envy"). Thus, Trump's experience of Clinton as Medusa echoes man's experience of powerful creative woman as a monstrously threatening reminder of his own narcissistic discontents. It also unravels man's need to demonize Medusa by victimization and then re-victimize her by demonization. Just as Medusa herself, an innocent beautiful maiden from Ovid's story, converts into a petrifying mirror of man's own monstrosity, so does the representation of Clinton and Clinton's defeat becomes a mirror through which an invisible lens of misogyny manifests itself.

\section{Introduction - The Medusa Defeated: An Aftermath}

Since the very day of the presidential election, many pundits, scholars and intellectuals have desperately been seeking a rational explanation for the defeat of Hillary Clinton. The New Yorker, for example, has just come out with sixteen distinguished opinions as to why the election ended as it did. Yet, in light of what was at stake in this election, in terms of individual and national wellbeing, the apathy of the turnout, with only fifty-two percent of eligible Americans bothering to vote, seems hard to explain. Why was President Obama, a very popular socalled lame duck president, who was anything but in terms of executive orders,

\footnotetext{
*Adjunct University of Haifa, Department of English Language and Literature, University of Haifa, Israel.

‡Chair, Department of English Language and Literature, University of Haifa, Israel.
} 
unable to bring out the male black vote? For that matter, how is it that in the $21^{\text {st }}$ century the popular vote or will of the majority in the United States can be overturned by the Electoral College? And how could so many people ignore or set aside the outrageously brutal, vicious, and undemocratic campaign run by Trump in order to reward him with the presidency?

Of course, any possible explanation cannot overlook the mistakes that Clinton made and was severely punished for. Because she was not immediately forthcoming with the rather innocuous story of the emails, they took on fantastic proportions and contributed to the picture of her as a dishonest candidate. Fact checking, Medusa be damned, showed Clinton to be the most honest of all candidates, including Bernie Sanders. Nevertheless, what negates that fact is that the conservative movement and its media are dominated by predatory men at Fox News (formerly Ailes and O'Reilly), among others, and their role model, the "pussy grabbing" Donald Trump.

Moreover, the bungling or grossly interfering behavior of the head of the FBI was an inappropriate and perhaps illegal act by a self-declared Republican that had a negative last-minute effect on the vote. Today, with the removal and legal problems of Michael Flynn, we also know more about Russian interference via hacking and deal making in the elections, something the entire western world has taken note of, as France has recently shown in its elections. Has the cyber age damaged democracy irrevocably? Is the Trump election an example of hyperreality, the ultimate victory of reality TV and its greatest star?

To return to the New Yorker, for Toni Morrison, the revenge of whiteness is the root cause of this presidential upset. Indeed, color, or more exactly having a black president for eight years, served as a motivation for some to return the presidency to the "safety" of white hands. Furthermore, the strain of antiintellectualism has been a constant thread winding its way through our political and cultural life, nurtured by the false notion that democracy means that 'my ignorance is just as good as your knowledge"' by those that as Isaac Asimov said, form "a cult of ignorance in the United States." In addition, there were those who feel left behind, those who despise Washington as the governing capital, those would choose only an outsider who promised to bring down the system crashing upon itself; and the list of events that ultimately caused what we view as a catastrophic occurrence goes on and on.

All of the above are legitimate explanations, but none of them is sufficient enough per se, as too many other factors have emerged to suggest a much more complex picture. Our contention is that there is no factor more powerful that the deeply ingrained misogyny; this claim is well represented by the parallels insistently made during the campaign between Hillary Clinton and the mythological figure of Medusa the Gorgon, one of the most odious and feared of symbols of a monstrous female throughout history. In this comparative analysis of the image of Medusa and its cultural, psychological, social implications, we

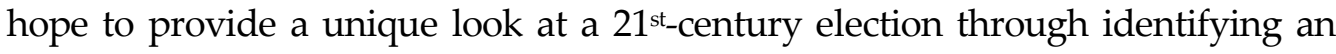


ancient symbol of the monstrous female that overshadowed the so-called issues.

\section{Such a Nasty Woman: Medusa's Head}

Freud's seminal Das Medusenhaupt, written in 1922, objectified Medusa and situated her in the space of the male point of view entirely, as a "phallic woman" incarnating man's fear of castration. The Post-Freudian body of interpretation, inspired by Freud's insights, continued to view Medusa through the male optic, as an infantile discovery of maternal sexuality and its denial. Medusa, again, was viewed through the eyes of the beholder, stripped of her subjectivity, through the narcissistically self-centered fear of the "monstrous feminine." Donald Trump expressed that well in the presidential debate when he called Clinton, "such a nasty woman."

Medusa's head represents the "irrepresentable" and embodies a terrifying other. The impossibility of looking at her was likened to the irrepresentability of death itself. Medusa was addressed as the ultimate mask of abysmal nothingness; she was referred to as a dichotomic part of the cycle of the "monster and the god," the Gorgon and the sun, and the "emptiness and the idol."1 This frame of interpretative reference shows how the rudimentary dread of the monstrous mask masks itself by unfolding a set of abstractions, all of which attempt to embrace the space of otherness, difference, and negativity.

Dumoulié refers to Walter Kruger's book Das Corgonenhaupt (Berlin, 1972) about the nuclear threat, wherein Medusa's mask is described as a "mirror of collective violence which leaves the Devil's mark on the individual, as well as being the image of death for those who look at it."2 Dumoulié's expression, "a mirror of collective violence which leaves the Devil's mark on the individual," captures the essence of what we discuss in terms of Medusa's monstrosity as internalization of the monstrous self of the other and subsequent reflection of this false self to the other. Moreover, it puts into context Donald Trump's claim on the campaign trail that Clinton was herself the devil. Or, rather, shall we say, just a mirror of collective violence, with many of Trump's projections onto Hillary whereby he echoes Dante's Inferno (IX, 55-57) and Milton's Paradise Lost (II, 611), where Medusa reappears in the role of guardian to the world of the dead who prevents the living from entering. Christian symbolism develops the ancient view of Medusa and attributes to her all the qualities associated with the Other Side - Sin, Devil, and Death. ${ }^{3}$

1. Camille Dumoulié, "On Medusa," in Companion to Literary Myths, ed. Pierre Brunel, trans. Wendy Allatson (London and New York: Routledge, 1992), 786.

2. Ibid., 786.

3. In a passage in the Book of Arthur (Vulgate version of Arthurian Romances, Vol. VII, Washington, 1913), Medusa appears as an embodiment of the Devil - a female monster, the "Ugly Semblance" who lives at the bottom of a river. Her power is exercised 
Medusa is a celebration of ambivalence; in Dumoulié's words, she constitutes "the very symbol of ambiguity."4 Her head was used in antiquity as an apotropaic mask, as a talisman which could both kill and redeem; her blood, given by Athena to Asclepius, with its twofold power to cure and destroy, is a "pharmakon;" she is a horror and a beauty, abomination and fascination. The male mythography positions Medusa on the border, separating the living from the dead. In Hesiod's Theogony (275 et. seq.) and in the Odyssey (XI, 633-5), Medusa is a guardian of terrifying places, the borders of the world and the kingdom of Hades. In Dante's Inferno (IX, 55-57) and Milton's Paradise Lost (II, 611) she reappears in the role of guardian to the world of the dead who prevents the living from entering.

\section{Medusa and Victimization}

The uncanny horror associated with Medusa seems to focus entirely on the image of death and, perhaps, conceals the original story that preceded Medusa's violent metamorphosis into a death-reminding monster and its consequential implications in interpreting the figure of Medusa. To address the question what makes Medusa's glance lethal, i.e. what is being seen in her eyes, it is essential that we understand why Medusa is the way she is. In Metamorphoses, Ovid leaves us one of the narratives recounting how a once shining beauty has become a monster. ${ }^{5}$

She was very lovely once, the hope of many

An envious suitor, and all of her beauties

Her hair most beautiful - at least I heard so

From one who claimed he had seen her. One day Neptune

Found her and raped her, in Minerva's temple,

And the goddess turned away, and hid her eyes

Behind her shield, and, punishing the outrage

As it deserved, she changed her hair to serpents,

And even now, to frighten evil doers,

She carries on her breastplate metal vipers

To serve as awful warning of her vengeance

(IV, lines 774-803, italics added)

by causing the waters to swallow people up. In a similar vein, a play by Calderon, addressing the adventures of Andromeda and Perseus (Fortunas de Andromeda y Perseo), has the hero, a new incarnation of the Saviour, defeating Medusa who is the personification of Death and Sin (Dumoulié, "On Medusa," 780).

4. Dumoulié, "On Medusa," 778.

5. Ovid, Metamorphoses, trans. A. D. Melville (Oxford and New York: Oxford University Press, 1986). 
This is a story of a chain of victimization: an innocent girl whose only flaw consisted of her beauty is sacrilegiously raped by the god of the seas in the temple of the Virgin Goddess, and, no less ruthlessly, turned into a monster as a just ("as it deserved") punishment for being thus violated by the indignant goddess of the temple. This story seems to articulate a meta-narrative of double violence inflicted upon women throughout history, it is a cultural punishment for victimization which leads to the punishment of the self by a woman and causes her ultimate dissociation from and hatred for her true (victimized) self. Perhaps, this helps to explain why the more women who came forward to complain about Trump's sexual abuses, the more Hillary seemed to be blamed.

Dumoulié, much like Trump, describes Medusa as "this terrible woman, the paragon of all women, who every man simultaneously fears and for whom Medusa is the mask. She is rendered a monster by the punishing maternal deity to serve as a mediating force - as a glittering shield of reflection separating her intact purity and man's monstrosity - to set herself apart from man's desire to destroy what he cannot have. This desire, subsequently, is translated into man's need to corrupt (deflower) the virgin, in terms of the ancient Greeks, to convert a maiden (parthenos) into a monster (gorgo). This behavior does much to explain Trump's relationships with women, grabbing them where, when and as he sees fit, as well as why Hillary, the monster, must still be locked up and totally isolated. The one tweet she made critical of Trump months after the election prompted Kelly Ann Conway to remind Clinton that she could still be imprisoned for her "crimes."

Apropos, locked up, is not that yet another mirror type metaphor? Let's examine the President's behavior and reevaluate who it is exactly that needs to be detained and restrained.

I hope no one will be shocked to discover that the President lies. Indeed, he lies in ways that no American president has ever dreamed of doing, including the infamous Richard Nixon. He lies in almost every tweet he releases; he has lied about President Obama's birthplace and citizenship, his wiretapping, JFK's assassination, incriminating Ted Cruz's father, American Muslims so-called cheering reaction on Sept 11 to the attack on NYC, the Iraq war, ISIS, NATO, military veterans, the size of his inaugural crowd, Chinese currency manipulation, Mexican immigrants as murderers and rapists, the anti-Semitism he is associated with, his connections to the alt right, the unemployment, rate, the economy, the murder rate, voter fraud and his groping of women. And that is just a partial list of his vicious lying accomplishments in four months in office. How convenient it must be to transfer all mostly imaginary outrages and so-called failures to women of the Democratic Party, with Senator Elizabeth Warren, whom Trump calls Pocahontas to mock her Native American heritage, joining the Medusa-like image of Hillary Clinton, as the nastiest duo of women in America.

As Alwes observes in her reading of Toni Morrison's The Bluest Eye, the selfinflicted violence of dissociation is "the primary source of victimization of women 
... [It] is a different, perhaps more brutal, type of rape because it penetrates and infects the woman with a paralyzing disease whose chief symptom is self-hatred." As a result of this "disease," the woman becomes "both a victim and a perpetrator of the act." 6 The process of woman's transformation into a monster is, then, an internal infection whereby her entire selfhood becomes perceived as monstrous. The distorted vision of herself as a monster is transmitted to the surface of her glance and reflected in her eyes. Once again, Hillary as Medusa helps explain the irrational hatred that so many Americans feel towards her, including American women.

Medusa has been defined as Athena's "negative double," from which she "found it necessary to set herself apart ... in order to assert her "own" identity."7 Athena must punish her seductive and sensual double for what she perceives as a violation of her temple, of her virgin (parthenos) self. Athena feels violated (that is why she cannot behold the spectacle and hides her face behind the shield) and experiences herself as a victim of Poseidon's male sacrilegious brutality. She reacts by converting a mortal victim into a mirror monster (a creature that can exist only as a reflection chained to the shield of another). The goddess disfigures Medusa's face with her own rage; she invades the subjectivity of Medusa's pain and converts a victim-monster into a symbol of herself, into a battle-weapon, into her invariable aegis and companion. In essence, Athena renders Medusa an extension of herself. The virgin goddess cannot tolerate her other seductive and attractive hypostasis; she needs to destroy her and then incorporate her monstrousness within herself, so as to "frighten evil doers" who may threaten her divine integrity.

Despite this violent separation by disfiguring and dehumanizing, then, Athena remains inseparably bound to Medusa. Quite remarkably, she affixes Medusa's head on the very shield that protected her from seeing the spectacle of rape, and "in battle or in anger she assumes the terrifying appearance of the monster." Instead of dissociating herself, Athena, in essence, reunites with her mortal monstrous hypostasis. Medusa's dyadic relations with Athena (a "punishing female deity") epitomize the symbiotic tension between two womendoubles.

\section{Medusa as a Mirror of the Monstrous Male}

With the advance of psychoanalysis, which further interrogated the concept of unified selfhood identical to itself, "Narcissus ... no longer saw himself reflected, but someone else, another." In this Geist of fin-de-siècle, where reflections

6. Karla Alwes, The Evil of Fulfillment, in Women and Violence in Literature: An Essay Collection, ed. Katherine Anne Ackley (New York: Garland Publications, 1990), 96-97.

7. Dumoulié, "On Medusa," 776. 
and source no longer coincided, the usual sense of order changed into a growing feeling of chaos and panic. Narcissus had become Medusa. The fatal frontality of Medusa blended with the compulsive frontality of Narcissus. ${ }^{8}$ This description describes, to a certain extent, the dynamic that developed between the two presidential candidates.

The Meduzian gaze interrogates the patriarchal/phallocentric/misogynist premise whereby woman is seen as an object of a male gaze and summons a dreadful reversal of the male prism of vision; that is to say, Medusa comes to represent a subversive female who is capable of turning man into an object of her gaze, and it is this capacity which decenters and undermines man's agency and which eventually stones man to death. ${ }^{9}$ What does he see, face and discover in Medusa's apparition that actually dethrones and overthrows him as a Subject and transforms him into an inanimate it, into the deadest object of creation?

Among the many visual representations of Medusa by male artists, Medusa's Head, by Caravaggio, is of particular interest, for it visualizes the fatal mirrorness of the monstrous face. His Medusa, allegedly a head of a decapitated man he saw in Rome, conveys the twofold horror of the monster that hath seen herself and him who hath seen himself in a monster. The whole countenance is an indescribable expression of pain, fear, disgust, entreaty, and the rage of helplessness; her eyes are inverted inside herself rather than toward the outside world; that is, they are not gazing. They also seem to be begging to be looked into, to remove the shield mirroring what she has become, what she is. It is a face of she/her who hath seen her/himself and who averts her gaze from the unbearability of this sight. Caravaggio manages to convey the horror of an intolerable duality. On one hand, there are clear signs that he painted himself reflected in his model's eyes; that is to say, he paints both a woman frightened by her own reflection and himself fearful of what a woman reflects to him. He captures the point at which the difference merges with sameness; it is I who is so different from me, it is I who gazes from me, from the mirror and from the strangers' eyes gazing through my eyes; it is both self and other mingled in their mutual fear of deathly dissolution. Caravaggio depicts Medusa as himself, as a Decapitated Man in the Mirror. Medusa's image is conspicuously desexualized and trans-sexualized as the universal gaze of one who has seen the Absolute Other (Double) - the angel of death before his eyes.

In essence, the Head of Medusa impersonates the interplay of ambivalence: the ambivalence of woman about herself, the ambivalence of man about both

8. Jean Clair, Méduse. Contribution à une anthropologie des arts visuel (Medusa. Contribution to an anthropology of the visual arts) (Paris: Gallimard, 1989).

9. "He [Perseus] saw the forms of men and beasts, made stone/By one look at Medusa's face (Ovid, Metamorphoses, IV, 774-777, italics added). Quite unequivocally, only men and beasts are victimized by Medusa's gaze - they become eviscerated of their essence, remaining empty forms - shapes, the shadows of themselves." 
himself and woman, and the ambivalence of woman about man who beholds her and herself as it is beheld. The complex game of inter-mirroring is responsible for persistent perceptual duplicity - seeing versus being seen, subjectivity versus objectification, victimizing versus being victimized. One can never see or determine with certainty the real victim in this dyad. The beholder overlooks Medusa's eyes and expression and chooses to focus on the serpentine frame of the portrait rather than on the portrait itself. This defensive detour to the vipers allows man to shelter and develop his understanding of the danger in the category of "yetzer ha-ra" (the evil drive) associated with serpents, and, analogically, with the female hair that is sensually provoking and thus a signifier of the "yetzer ha-ra" at work.

Not accidentally, Lilith is the beauty with long hair, and Medusa's hair is addressed as the most beautiful part of her external appearance as a seductive maiden. The focus on the viperine hair as the phallic representation distracts attention from and defers the necessity to cope with the meaning of Medusa's eyes and understand the reason for the paralysis that immediately seizes the beholder. It is the uncanny feeling of familiarity (déjà vu) that pervades the perception and features the sensation when looking into Medusa's eyes.

In her Mirror, Sylvia Plath describes a Medusa who is aware of herself, who is rather "the mirror who takes a fierce pleasure in her uncompromising veracity and who, by rejecting the role of passive reflector for a more creative autonomy, becomes, in that same male-inscribed view, a devouring monster."10 Can we recognize Hillary Clinton on the campaign trail?

\section{Behind the Mask}

Medusa's expression is a conglomerate of pain, rage, and horror, altogether unbearable. Simultaneously, the Iron Mask of a monster that hides and, in fact, replaces Medusa's real face communicates the concealed plea to be recognized as a non-monster, a plea that is distorted by the hideous expression of helplessly raging pain. Through the mask, the maiden implores to be seen, recognized, rescued, and returned to what she used to be, to what she really is. Alas, her eyes can only express the deadness of her violated and subsequently obliterated self and reflect to the beholder the paralyzing irreversibility which he comes to perceive as his own deadness.

At the moment of her decapitation, Medusa is pregnant, which constitutes another crucial dimension of her monstrous victimization. As noticed earlier, woman's procreative power and, consequently, the markers of her fecundity

10. William Freedman, "The Monster in Plath's 'Mirror'," Papers on Language and Literature 108, no. 5 (1993): 152-169. 
constitute one of the most profound threats to the narcissist's psychic integrity, ${ }^{11}$ and, as a result, one of his main targets in victimizing the woman-double, his mirror. We may recall how Donald Trump accused Megan Kelly, because of her aggressive questioning of him, as bleeding from various orifices of her body. "There Was Blood Coming Out of her eyes, blood coming out of her wherever" (Donald Trump interview on $\mathrm{CNN}$ ). ${ }^{12}$

Robert Graves believes that the myth of Perseus preserves the memory of the conflicts that occurred between men and women in the transition from a matriarchal to a patriarchal society. ${ }^{13}$ In fact, the function of the Gorgon's mask was to keep men at a safe distance from the sacred ceremonies and mysteries reserved for women, i.e. those which celebrated the Triple Goddess, the Moon. In his White Goddess, Graves reminds us that the Orphic poems referred to the full moon as the Gorgon's head. ${ }^{14}$ The mask was also worn by young maidens to ward off male lust. The episode of Perseus's victory over Medusa represents, in these terms, the end of female ascendancy and the taking over of the temples by men, who had become the masters of the divine which Medusa's head had concealed from them. The Greek understanding is characterized by deep awareness of Medusa's meaning as a mythologeme and cultural construct, its spiritual and psychic significance. "Perseus's victory," i.e. the patriarchal transformation of culture, disavowed woman from her authentic selfhood and replaced it with passive reflexivity in his narrative of reality and of his selfhood. Medusa (and the feminine self in general, it can be assumed) undergoes triple victimization: she is violated, she is punished for being violated by being turned into a monster, and eventually she is punished (slain pregnant in her sleep) for being a monster. Or, perhaps, in our times, she is punished by losing a

11. The medieval Talmudist thinker Nahmanides unequivocally draws a parallel between a menstruating woman and a Medusian monster capable of killing with her mere glance: The glance of a menstruous woman poisons the air ... She is like a viper who kills with her glance. How much more harm will she bring a man who sleeps with her? She is a pariah; men and women will distance themselves from her and she will sit alone and speak to no one ... the dust on which she walks is impure like the dust defiled by the bones of the dead. And the rabbis said "Even her glance brings harm." [p. 177]. The Hebrew rules of "niddah," within the male-discoursed legislation of family purity, reveal and re-veil man's fear of female bodily excess - secretions - etymologically, secret/ "hafrashot" - active expulsion of the internal, made public; therefore, through "the power of inspection and supervision given to men over her activities of recurrent purification, takes away her power, relegating her to the margins of society." [p. 658]. [Jane M. Ussher, Managing the Monstrous Feminine. Regulating the Reproductive Body (London and New York: Routledge, Taylor \& Francis Group, 2006)].

12. Retrieved from goo.gl/QxhlBK.

13. Robert Graves, Greek Myths: Complete Edition (London: Penguin Books, 1992).

14. Graves, The White Goddess: A Historical Grammar of Poetic Myth, ed. Grevel Lindop (Manchester: Carcanet, 1997). 
presidential election. Some versions of the myth say that Medusa actually died not by the sword but from the horror of having seen herself - shown to her by Perseus in the shield. In these terms, she dies when violently confronted with the double (the monster) that has come to replace her face and essence, and in the mirroring shield she catches a glimpse of a "terrible fish," that is, of herself, maimed and disfigured by others. ${ }^{15}$

\section{A Muse or a Curse? Medusa as a Creative Woman}

In the language of Graves's White Goddess, ${ }^{16}$ woman can be either muse or nothing; in terms of this discussion, Medusa is a muse for a "Dionysian artist," that is, nothing but an object of the artist's search for Truth, which turns out to signify for him the Forbidden Knowledge. A woman deciding to engage herself in poetry (that is, to be creative, political and productive and not only re-productive, has two options in the male ontological world: she may be either a silent Muse inspiring men with her presence only, or a Terrible Mother-Deity (Lilith, Medusa, and others) devouring her children. Hence, in the world of male mythmaking and signification, woman cannot be creative in the full meaning of the word; rather, she is bound to represent a passive participator in the male creative process.

In this discourse, a creative woman is a monster; more precisely, she is a Medusa who can paralyze man's artistic vitality and petrify him in front of the mirror of his own monstrous self. For the sake of man's survival, Medusa needs be neutralized by the only weapons available to man (Perseus) - the defensive shield of deflection. In our world, that corresponds to Trump and his followers' hysterical cries to "lock her (Clinton) up." For Medusa, this defensive shield forces her to see herself through the eyes of the other. To paraphrase Bakhtin's "Man in the Mirror," "the stranger's eyes are now gazing from her eyes;" her point of view on herself, and, subsequently, her self is usurped by the point of view of the stranger. Woman's creativity, or, the ability to express herself not just procreatively, becomes a painful metaphor for pathology, for being "out of her mind;" indeed, as Cixous observes in the Newly Born Woman, "either woman is passive or

15. In Freedman's words, the terrible fish - an image from Plath's mirror, "is not simply the time-transformed identity of the young girl; it is the Hydean alter-ego of the mirror or lake in whose depths it is shudderingly disclosed" (Freedman, "The Monster in Plath's 'Mirror'," 157).

16. White Goddess is an attempt by male to reverse the situation and to restore the lost feminine in its multiplicity, ambiguity, and ultimate ambivalence - the intimate connection between birth and death, lust and life, all of them united in one image, that inspires the real poetry. White Goddess comprises in a chaotic (female language) form, inconsistent listing and combinations of the triple goddess qualities. The male comes to terms with the frightening feminine and agrees to accept it, as a cult and veneration. 
she does not exist"17 (cf. with Graves's view of woman as either Muse or nothing).

Since Clinton is anything but passive, she should not exist on the political playing field and certainly cannot be president. Medusa can exist only in the shape of another self which provides her with a spurious sense of legitimacy: not accidentally, as Axelrod observes in regard to Plath's double self, she "had located her double not in her mother or husband, not in another at all, but in her creativity, which was marked by her texts."18

Woman's creativity is feared and subsequently demonized by man and then by woman herself. Thus, it is not difficult to understand why women can hate Clinton as well. This fearful demonization is an expression of what can be termed "uterus envy," a primary man's experience which he - defensively - has projected upon woman, forcing her to shelter her self-definition within the space of negation and denial, in terms of absence; in other words, man has constituted woman as "lack" for what she has not got, thereby indulging and absolving himself from the sense of inferiority for what he cannot do. In essence, man is initially estranged from the process of reproduction - woman is perceived as she who has usurped his vitality (semen) and, in these terms, the fruit of her entrails is certainly "not his." Woman's pregnancy evokes man's anger at being dispossessed and alienated from himself, while the process of delivery further exacerbates the sense of incapacity and not belonging, the sense of being a "guest to his own wedding."19

Uterus envy informs man's narrative of "wandering womb," which pathologizes and marginalizes the reproductive female body, thereby presenting woman to herself as an initially divided self, not quite responsible for her moods, and injecting her with the view of herself as a Jekyll and Hyde personality type. Perceived and feared by man as untrustworthy and unstable, a slave to her (inferior) biochemistry, woman comes to view herself as untrustworthy and unreliable; as a result, she seeks to be defined and "cured" by that very agency that defined her from the outset as such, for she has no other narrative of herself available. Her agency has been structured by the language of pathology; her (pro) creativity has been rendered synonymous with madness, i.e. being transgressively "out of her mind," just to absolve man from the overwhelming burden of all-consuming, destructive envy.

The woman as a monster in the mirror reintroduces man into his own vision

17. Helene Cixous \& Catherine Clement, The Newly Born Woman, trans. Betsy Wing (Minneapolis: University of Minnesota Press, 1986), 349.

18. Steven Gould Axelrod, "There Are Two of Me Now," in Sylvia Plath: The Wound and the Cure of Words (Baltimore: The John Hopkins University Press, 1990), 178-236.

19. The concept of uterus envy resonates with Klein's vision of primary envy, a controversial idea, found unacceptable by many psychoanalysts, referring to a "constitutional instinctive destructive factor at work" The first object to be envied, according to Klein, is the maternal breast. [Melanie Klein, Envy and Gratitude and other works - 1946-1963 (New York: The Free Press, a Division of McMillan, 1984), 212]. 
and perception of the female as overwhelmingly and voraciously monstrous: thus, the mirror of Plath's creation is perceived as a cannibal Charybdis who either has not yet identified the enemy or is not prepared to attack it. Indeed, a woman-double is unable to identify as her enemy $\mathrm{HE}$ who has come to destroy her/take possession of her soul/deprive her of her (pro) creativity. Either passively or actively, the woman-as-mirror clearly participates in the circle of her own desubjectification and annihilation by the double-man. Perceived as a "cannibal Charybdis," she is ready to "swallow everything she sees" and "eat men like air" ("Lady Lazarus"). Having assimilated the mirrorness, imposed upon her, she anesthetizes and dissects her wounded true self, as she experiences this other self as dead). And for the sake of survival, she becomes a mirror, "silver and exact," with no preconceptions, or dangerously painful feelings ("unmisted by love or dislike") and assumes the role of an objective and controlled observer - "gazer" of other women, usurping or, rather, "buying" the male truth about "what she is":

I am not cruel, only truthful -

The eye of a little god, four-cornered (Mirror, lines 3-4).

And yet, despite this calculated detachment, a mute monster rises out of her entrails, a terrible fish of her implanted self.

In her manifesto of feminine subjectivity, Laugh of the Medusa, Cixous addresses (or, rather, attacks) and exposes the phallocentric tenets of linguistic structuring:

"Beware, my friend, of the signifier that would take you back to the authority of a signified! Beware of diagnoses that would reduce your generative powers ... Break out of the circles; don't remain within the psychoanalytic closure. Take a look around, then cut through!"20

The woman can discover herself as a solid identity that is neither transparent nor reflexive, shatter the mirror mask imposed upon her, and reclaim her subjectivity only by reinventing herself in terms of her own narrative and by discrediting and dismantling the other's narrative on herself. After she recollects the fragments of her own self and reshapes the shattered mirror, she can deduce her true identity and trace her subjectivity back to when it was not yet defined - to the pre-linguistic, pre-orderly world. It is in this space that the integrity of emotional image can be found and experienced, in the frame of what Zucker termed "bastard reasoning," i.e. "thinking without the father, as a bastard, in the space between the "feminine" phase and the paternal phase of the symbolic" in order to achieve "a recuperation of the trope of the feminine," where ambivalence can be fully perceived as unity; it is that borderline point

20. Cixous \& Clement, The Newly Born Woman, 892. 
where we can see Medusa's beautiful face laugh. ${ }^{21}$

\section{Conclusion: Mourning the Defeat, Laughing with Medusa}

And that is where we find Hillary Clinton today. She can only laugh at the retransformation she has been forced to undergo. From someone who enjoyed a $65 \%$ popularity rating in the US just a few years ago, to a woman whose Medusa-like presence should cause her nothing but shame and horror at whom, according to Donald Trump, she had become. As Medusa, Hillary Clinton has become a dangerous woman, one that must be locked up, to once again make the world safe for male patriarchy. Perhaps that is why the Trump camp has yet to abandon fully their ongoing slogan, "lock her up."

In a prescient if not frightening election prediction we need only have turned to the philosopher Richard Rorty: He was one person who got the election right, even though he had been dead for nine years at the time of the vote. "Something will crack," he wrote:

The nonsuburban electorate will decide that the system has failed and start looking around for a strongman to vote for-someone willing to assure them that, once he is elected, the smug bureaucrats, tricky lawyers, overpaid bond salesmen, and postmodernist professors will no longer be calling the shots ... . One thing that is very likely to happen is that the gains made in the past forty years by black and brown Americans, and by homosexuals, will be wiped out. Jocular contempt for women will come back into fashion ... . All the resentment which badly educated Americans feel about having their manners dictated to them by college graduates will find an outlet. ${ }^{22}$

And so it happened, with half the voters taking out their rage on the hatefully feared feminine. To understand a phenomenon is helpful, but is there possibly a solution? What should or can possibly be done about a situation in which the quest for post-truth combines with such a potent symbol of the ongoing struggle with our self-fulfilling fear of demonized womanhood?

A modest beginning might be extracted from Trump's most prescient tweet, which he issued in 2014: "Can a president be impeached for gross incompetence?" Absolutely.

21. Lisa Zucker, "Biodegradability: Floating on the surface of culture" (presentation, conference Rethinking Culture, University of Montreal, April 3-5, 1992).

22. Richard Rorty, Achieving our Country (United States: Harvard University Press, 1998). 
Vol. 5, No. 3 Clebanov et al.: Gaze of the Medusa: The Defeat of Hillary Clinton

\section{Bibliography}

Alwes, Karla. The Evil of Fulfillment. In Women and Violence in Literature: An Essay Collection, edited by Katherine Anne Ackley. New York: Garland Publications, 1990.

Axelrod, Steven Gould. "There Are Two of Me Now." In Sylvia Plath: The Wound and the Cure of Words. Baltimore: The John Hopkins University Press, 1990.

Cixous, Helene, \& Clement, Catherine. The Newly Born Woman. Translated by Betsy Wing. Minneapolis: University of Minnesota Press, 1986.

Clair, Jean. Méduse. Contribution à une anthropologie des arts visuel (Medusa. Contribution to an anthropology of the visual arts). Paris: Gallimard, 1989.

Dumoulié, Camille. "On Medusa." In Companion to Literary Myths, edited by Pierre Brunel, translated by Wendy Allatson. London and New York: Routledge, 1992.

Freedman, William. "The Monster in Plath's 'Mirror'." Papers on Language and Literature 108, no. 5 (1993): 152-169.

Graves, Robert. The White Goddess: A Historical Grammar of Poetic Myth, edited by Grevel Lindop. Manchester: Carcanet, 1997.

Graves, Robert. Greek Myths: Complete Edition. London: Penguin Books, 1992.

Klein, Melanie. Envy and Gratitude and other works - 1946-1963. New York: The Free Press, a Division of McMillan, Inc. 1984.

Ovid. Metamorphoses. Translated by A. D. Melville. Oxford and New York: Oxford University Press, 1986.

Rorty, Richard. Achieving our Country. United States: Harvard University Press, 1998.

Ussher, Jane M. Managing the Monstrous Feminine. Regulating the Reproductive Body. London and New York: Routledge, Taylor \& Francis Group, 2006.

Zucker, Lisa. "Biodegradability: Floating on the surface of culture." Presentation at the Conference Rethinking Culture. University of Montreal, April 3-5, 1992. 